\title{
Visual snow syndrome after start of citalopram—novel insights into underlying pathophysiology
}

\author{
Ozan E. Eren ${ }^{1}$ (D) $\cdot$ Florian Schöberl $^{1} \cdot$ Christoph J. Schankin ${ }^{1,2} \cdot$ Andreas Straube $^{1}$
}

Received: 9 August 2020 / Accepted: 10 September 2020 / Published online: 16 September 2020

(C) The Author(s) 2020

Dear Sirs,

Patients with visual snow (VS) describe tiny flickering dots in the entire visual field often compared with the TV static in case of a badly adjusted analog signal. It can be episodic with migraine [1], but is debilitating when continuously present. When occurring together with visual (palinopsia, enhanced entoptic phenomena, photophobia, and nyctalopia) and a variety of non-visual symptoms (tinnitus, concentration loss, etc.), one speaks of visual snow syndrome (VSS) [2].

Pathophysiological mechanisms are still not well-understood, and pharmacological treatment options are sparse. We present a case of VSS onset after citalopram intake and discuss this constellation in the light of "Hallucinogen Persisting Perception Disorder" (HPPD) with possible shared receptor mechanisms.

\section{Case report}

Two weeks after starting with citalopram $20 \mathrm{mg}$ to treat postpartum depression, a 31-year-old female developed visual disturbances in terms of white and black dots in the entire visual field, intermittent bright flashes, entoptic phenomena, swirls, photophobia, and additionally increased irritability to external sensory cues. Past medical history was unremarkable except for episodic migraine without aura (every 8 weeks; MIDAS $0 \mathrm{p})$. There was moderate anxiety and depression as assessed by the GAD-7 anxiety scale (7p) and the PHQ-9 depression scale (10p) at that time. There was no use of hallucinogenic

Ozan E. Eren

ozan.eren@med.uni-muenchen.de

1 Department of Neurology, LMU Munich, University Hospital-Großhadern, Marchioninistr. 15, 81377 Munich, Germany

2 Department of Neurology, Inselspital, Bern University Hospital, University of Bern, Bern, Switzerland substances in the past. Diagnostics including thorough clinical neurological and ophthalmological examination, visual evoked potentials ( $16 \mathrm{k}$ and $64 \mathrm{k}$ ), and MRI-scan of the brain were unremarkable. VSS persisted after stopping citalopram. An additionally used causality assessment tool (CAT) for adverse drug reaction (ADR), namely the Liverpool ADR CAT, indicated a possible adverse drug reaction [3].

\section{Case discussion}

Individual symptoms of VSS can overlap with conditions such as visual migraine aura [2, 4] and HPPD [5, 6]. Particularly, VSS and HPPD symptoms largely overlap and therefore might share common pathophysiological mechanisms in terms of involved cerebral networks and changes in synaptic transmission. The drug lysergic acid diethylamide (LSD) mediates its hallucinogenic effects mainly via activating the serotonergic $5 \mathrm{HT}_{2 \mathrm{a}}$-receptor [7]. Even one-time consumption of LSD can cause persistent HPPD with VS-like symptoms [6]. Interestingly, there are reports on visual sensations arising years after LSD abuse triggered by the intake of selective serotonin reuptake inhibitors (SSRI) in patients with former HPPD [7]. Regarding our case, the hypothesis arises that changes in serotonergic synaptic transmission, particularly via $5 \mathrm{HT}_{2 \mathrm{a}}$-receptors, in primary and/or secondary visual cortical areas might underlie VSS as well as HPPD. Functional imaging studies revealed increased metabolism in secondary visual cortical areas such as the lingual gyrus in VSS [4]. There is evidence for a particularly high density of $5 \mathrm{HT}_{2}$-receptors of projections from the lateral geniculate body of the thalamus to the primary visual cortex $[8,9]$. It is hypothesized that a shift in the balance of excitatory and inhibitory synaptic transmission in the visual cortex towards more excitation due to a decrease in either the number or the functional activation of inhibitory serotonergic interneurons might play a crucial role in HPPD after LSD abuse [6]. Thus, in subjects with an increased vulnerability, VSS might also be 
triggered by minor changes in serotonergic transmission due to SSRI, like in our case. Further evidence for the important role of serotonergic transmission derives from the at least partial effectiveness of lamotrigine in both conditions [10-12], as lamotrigine also has an inhibitory function on $5 \mathrm{HT}_{2 \mathrm{a}}$-receptors [13].

\section{Conclusion}

This case report gives further insight for a possible role of changes in serotonergic transmission in brain regions important for visual processing as potentially underlying pathophysiological mechanism of VSS. Furthermore, common pathophysiological changes in VSS and HPPD on the level of cerebral network activations and synaptic transmission seem plausible.

Authors' contributions OEE: Acquisition, conception of the work, writing of the manuscript.

FS: Revising of the manuscript.

CJS: Revising of the manuscript.

AS: Conception of the work, revising of the manuscript.

All authors approved the final version of the manuscript.

Funding Open Access funding enabled and organized by Projekt DEAL. This work is funded by the Deutsche Migräne- und Kopfschmerzgesellschaft (www.dmkg.de), the Eye On Vision Foundation (www.eyeonvision.org), the Baasch Medicus Foundation, and the Friedrich-Baur Foundation.

Data availability The datasets used and/or analyzed during the current study are available from the corresponding author on reasonable request.

\section{Compliance with ethical standards}

Conflict of interest OE Eren has received honoraria for consulting within the past three years from Novartis Pharma. FS has nothing to report. CJ Schankin has received honoraria for consulting and lectures within the past 3 years from Novartis, Eli Lilly, Allergan, Almirall, Amgen, Teva Pharmaceuticals, MindMed, and Grünenthal outside the submitted work. AS has received honoraria for consulting and lectures within the past 3 years from Allergan Pharma, Bayer, Lilly, Novartis Pharma, Sanofi, and TEVA.

Ethics approval The work was conducted in accordance with the Declaration of Helsinki and approved by the ethics committee of the Ludwig Maximilians University Munich (227-15). The subject was recruited between 2015 and 2017 and gave written informed consent.

Consent to publish Not applicable.

Open Access This article is licensed under a Creative Commons Attribution 4.0 International License, which permits use, sharing, adaptation, distribution and reproduction in any medium or format, as long as you give appropriate credit to the original author(s) and the source, provide a link to the Creative Commons licence, and indicate if changes were made. The images or other third party material in this article are included in the article's Creative Commons licence, unless indicated otherwise in a credit line to the material. If material is not included in the article's Creative Commons licence and your intended use is not permitted by statutory regulation or exceeds the permitted use, you will need to obtain permission directly from the copyright holder. To view a copy of this licence, visit http://creativecommons.org/licenses/by/4.0/.

\section{References}

1. Hodak J, Fischer U, Bassetti CLA, Schankin CJ (2019) Episodic visual snow associated with migraine attacks. JAMA Neurol 77: 392-393. https://doi.org/10.1001/jamaneurol.2019.4050

2. Schankin C, Maniyar FH, Digre KB, Goadsby PJ (2014) "Visual snow" - a disorder distinct from persistent migraine aura. Brain 137: 1419-1428. https://doi.org/10.1093/brain/awu050

3. Gallagher RM, Kirkham JJ, Mason JR, Bird KA, Williamson PR, Nunn AJ, Turner MA, Smyth RL, Pirmohamed M (2011) Development and inter-rater reliability of the Liverpool adverse drug reaction causality assessment tool. PLoS One 6:e28096. https://doi.org/10.1371/journal.pone.0028096

4. Schankin CJ, Maniyar FH, Sprenger T, Chou DE, Eller M, Goadsby PJ (2014) The relation between migraine, typical migraine aura and "visual snow.". Headache 54:957-966. https:// doi.org/10.1111/head.12378

5. Halpern JH, Pope HG (2003) Hallucinogen persisting perception disorder: what do we know after 50 years? Drug Alcohol Depend 69:109-119. https://doi.org/10.1016/S0376-8716(02)00306-X

6. Abraham HD, Aldridge AM, Gogia P (1996) The psychopharmacology of hallucinogens. Neuropsychopharmacology 14:285-298. https://doi.org/10.1016/0893-133X(95)00136-2

7. Goldman S, Galarneau D, Friedman R (2007) New onset LSD flashback syndrome triggered by the initiation of SSRIs. Ochsner J 7:37-39

8. Pazos A, González AM, Waeber C, Palacios JM (1991) Chapter 4 multiple serotonin receptors in the human brain. In: Mendelsohn FAO, Paxinos G (eds) Receptors in the human nervous system. Academic Press, pp 71-101

9. Burnet PWJ, Eastwood SL, Lacey K, Harrison PJ (1995) The distribution of 5-HT1A and 5-HT2A receptor mRNA in human brain. Brain Res 676:157-168. https://doi.org/10.1016/0006-8993(95) 00104-X

10. Rothrock JF (1997) Successful Treatment of Persistent Migraine Aura with Divalproex Sodium. Neurology 48:261-262. https:// doi.org/10.1212/WNL.48.1.261

11. Unal-Cevik I, Yildiz FG (2015) Visual snow in migraine with aura: further characterization by brain imaging, electrophysiology, and treatment - case report. Headache 55:1436-1441. https://doi.org/ 10.1111/head. 12628

12. Martinotti G, Santacroce R, Pettorruso M, Montemitro C, Spano M, Lorusso M, di Giannantonio M, Lerner A (2018) Hallucinogen persisting perception disorder: etiology, clinical features, and therapeutic perspectives. Brain Sci 8:. https://doi.org/10.3390/ brainsci8030047

13. Wishart DS, Feunang YD, Guo AC, Lo EJ, Marcu A, Grant JR, Sajed T, Johnson D, Li C, Sayeeda Z, Assempour N, Iynkkaran I, Liu Y, Maciejewski A, Gale N, Wilson A, Chin L, Cummings R, le D, Pon A, Knox C, Wilson M (2018) DrugBank 5.0: a major update to the DrugBank database for 2018. Nucleic Acids Res 46:D1074 D1082. https://doi.org/10.1093/nar/gkx1037

Publisher's note Springer Nature remains neutral with regard to jurisdictional claims in published maps and institutional affiliations. 